Article

\title{
Samaritans in the New Testament ${ }^{+}$
}

\section{Martina Böhm}

Fachbereich Evangelische Theologie, Fakultät für Geisteswissenschaften, Universität Hamburg, 20354 Hamburg, Germany; martina.boehm@uni-hamburg.de

† This article is a summary of initial, previously unpublished considerations from a larger study in German that has been in progress since 2018. I would like to thank Kaja Wieczorek and Jocasta Godlieb for the translation.

Received: 13 February 2020; Accepted: 18 March 2020; Published: 23 March 2020

check for

\begin{abstract}
Four New Testament writings mention Samaritans and Samaria-Luke-Acts, John, and Matthew. We must consider that all Samaritan texts in the New Testament are based on a historically correct knowledge of the cult of YHWH worshippers in Samaria oriented towards the Gerizim. If the YHWH admirers in Samaria are to be understood as one of the two independent "Israel" denominations that existed in the Palestinian heartland during the post-exilic period, consequently, in John, Matthew, and Luke-Acts, attention is paid to their understanding of the ecclesiological significance of "Israel" and to Christological aspects. Moreover, the authors of the Gospels reflect a semantically young phenomenon, when $\Sigma \alpha \mu \alpha \rho \tilde{\tau} \tau \alpha \iota$ is understood beyond the ethnicon as a term for a group religiously distinct from Judaism. At the time of Paul, the term "Samaritan" had not yet been established to refer to the religiously defined group. This means that care must be taken when interpreting the term "Israel" and "Israelites" in all Jewish or Jewish-Christian texts written before 70 A.D. This also applies to Paul: when Paul speaks of "Israel", "Israelites", and "circumcision", he could have consciously used inclusive terminology that, in principle, included the (later named) "Samaritans" in the diaspora.
\end{abstract}

Keywords: Luke-Acts; Gospel of Matthew; Gospel of John; Pauline letters; 2Kings; Septuagint; inscriptions (Greek); Josephus; Israel/Israelites; historical Jesus; Mount Gerizim; post-exilic period; Pentateuch; Moses; Jerusalem; diaspora; Delos; Ben Sira

\section{Which Texts Are Relevant?}

\subsection{The Classical New Testament Samaritan Texts and Historical and Hermeneutical Questions Connected with Them}

Although the Greek terms $\Sigma \alpha \mu \alpha \rho i \tau \eta \varsigma, \Sigma \alpha \mu \alpha \rho \tilde{\imath} \tau \iota \varsigma$, and $\Sigma \alpha \mu \alpha \rho \tilde{\imath} \tau \alpha$ are only found in a few New Testament writings, they are sometimes associated with very prominent narratives. The most famous is certainly the parable of the Good Samaritan in Luke 10:30-37, but the story of Jesus and a woman at the well in John 4 is also one of the most famous Samaritan texts of the New Testament. In the Gospel of Luke, besides Luke 10:25-37, there are two other texts in which one $\Sigma \alpha \mu \alpha \rho i \tau \eta \varsigma$ or several $\Sigma \alpha \mu \alpha \rho \tilde{\tau} \tau \alpha \mathrm{l}$ appear: Luke 9:51-56 (the inhabitants of a Samaritan village refuse to give hospitality to Jesus on his way to Jerusalem) and Luke 17:11-19 (the story of the grateful Samaritan leper). In addition, for the author of the Third Gospel's understanding of the Samaritans, the notes and a narrative about the post-Easter Samaritan mission in Acts must be considered: Acts 1:8; 8:1; 4-25; 9:31; 15:3. In the Gospel of John, besides the narrative in John 4:4-42, there is another note in John 8:48: Here, Jesus is accused by 
his opponents of being a Samaritan and possessed by a demon. ${ }^{1}$ The Gospel of Matthew mentions the Samaritans only once: at the beginning of the of the missionary discourse Jesus instructs the disciples in Matt 10:5-6 "Go nowhere among the Gentiles and enter no town of the Samaritans, but rather go to the lost sheep of the house of Israel." ${ }^{2}$

In sum, four New Testament writings (but three authors) mention Samaritans and Samaria. The author of Luke-Acts offers by far the most texts and documents. For each of the three authors-Matthew, Luke, and John - it is necessary to consider separately what image that author has of the Samaritans and in what sense he speaks of them: Is it in a general, political-geographical sense about the population of the region Samaria, or is it about Samaritans in the sense of a primarily religiously defined group? If the latter is true, in what way are the Samaritans religiously defined and theologically classified? Here, further-reaching questions come into play, such as those that are made tangible due to a real knowledge of the religious situation in Samaria or participation in literarily mediated images, for example, in $2 \mathrm{Kgs}$ 17:24-41 in the Masoretic Text as well as in the Septuagint or with Josephus in Ant 9,277-282.288-291. In addition, the question about the Jesus tradition arises in the area of the Gospel tradition: to what degree can one start from contact between the historical Jesus and Samaritans?

However, the respective context in all texts now shows more or less clearly that all three authors are concerned with more than the inhabitants of Samaria in geographical-political terms. The persons designated as $\Sigma \alpha \mu \alpha \rho i \tau \eta \zeta, \Sigma \alpha \mu \alpha \rho \tilde{\tau} \tau \iota \varsigma$, and $\Sigma \alpha \mu \alpha \rho \tilde{\tau} \tau \alpha$ l, as well as the literarily formed figure of the Good Samaritan, must instead be understood in the religious sense. ${ }^{3}$ However, the question behind the Gospels concerning the understanding of $\Sigma \alpha \mu \alpha \rho \tilde{i} \tau \alpha \iota$ in the recorded tradition, which possibly even goes back to the historical Jesus, finds no reliable statements. All the Samaritan texts of the Gospels are special material ("Sondergut"), and because the comparative material is missing, it is not easy to decide whether, and to what extent, this special material goes back to older traditions. This also makes the question of the historical Jesus difficult. It is difficult to reconstruct which attitude the historical Jesus adopted with respect to the Samaritans in the spectrum of inner-Jewish relations and whether he himself formed and told the story of the Good Samaritan. This can-if at all—only be cautiously considered regarding its plausibility. ${ }^{4}$

The classical question about the Samaritans in the New Testament is usually limited to research focused on the aforementioned Gospel texts, ${ }^{5}$ as it provides a solid source for the terminology. More recent research results, above all from the fields of archaeology, Old Testament studies, and non-Biblical Jewish literature ${ }^{6}$, however, raise the hermeneutical question of whether the usual

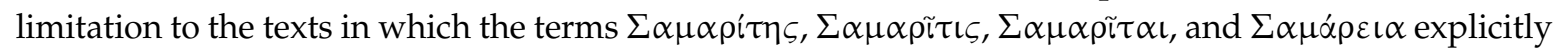
appear is sufficient. Increasingly, the field of Old Testament studies is providing insight-from the point of view of religious history, which is contrary to the biblical representations in the post-exilic period-on the fact that there were not only one, but two theologically and sociologically relevant leading figures in the Palestinian heartland. Thus, there were also two important Yahwisms, each with

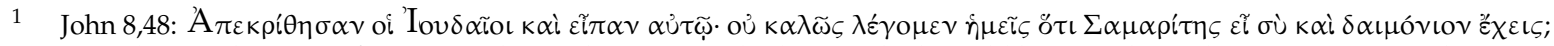
according to the view of Hartwig Thyen, this is a Hendiadyoin, which could be paraphrased as: "Aren't we right to say you're one of those crazy Samaritans?" See (Thyen 2005, p. 447).

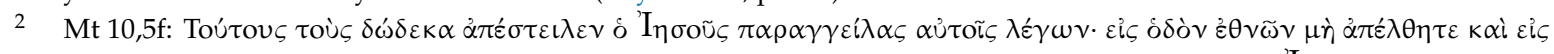

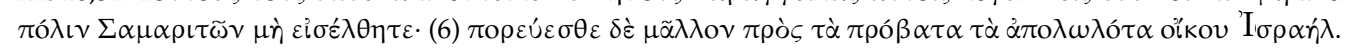

3 The discussion on each of the New Testament authors is long and cannot be reproduced here in detail. The thesis reflects the opinion of the author of this article.

4 See (Böhm 2017, p. 356).

5 For a general overview, see (Pummer 1993, pp. 167-71; Lindemann 1993; Pummer 2009, pp. 27-37; Frey 2012; Pummer 2016, pp. 36-46; Böhm 2017). For the texts in the Gospel of John and in the Gospel of Matthew, see (Zangenberg 1998). For the texts in the Gospel of Luke, Acts, and Matthew, see (Böhm 1999).

6 For an overview, see (Pummer 2016, pp. 26-118; Hensel 2016). 
its own YHWH sanctuary and its own claim to be "Israel". ${ }^{7}$ If one summarizes the previous results in the shortest form, both Yahwisms existed from the Persian time up to the 2nd century B.C., side by side, in a relationship that was not shattered ${ }^{8}$ by deep conflicts, as had been the previous assumption, but which had found a compromise document in the common Pentateuch. The post-exilic Jewish biblical and non-biblical literature shows that the coexistence of both groups was increasingly burdened by conflicts only from 200 B.C. onwards. Since the Hasmonaean period, tensions increased, and the YHWH admirers in the region of Samaria were transformed from "Israelites" to "foreigners". 9 . After the Hasmonaean attacks on Samaria and the associated destruction of the city and the sanctuary on Mount Gerizim, i.e., at the end of the 2nd century B.C., group-specific peculiarities developed and grew in both Israelite groupings, and border demarcations increasingly took hold. ${ }^{10}$ Thus, in Old Testament studies, there is currently a gradually growing sensitivity to the fact that, from a historical perspective, the Samaritans of the biblical era must have been more important than their biblical presentation would have us believe. ${ }^{11}$ We must therefore distinguish between the biblical and historical view of the history of Israel and recognize the divergence within it. ${ }^{12}$

The YHWH worshippers in Samaria, who came from old Israelite traditions that were continuously cultivated, cannot have been a marginal religious phenomenon in New Testament times in terms of their number and importance ${ }^{13}$, even though their sanctuary on Mount Gerizim and the large temple city surrounding it had been permanently destroyed at the end of the 2nd century B.C. and could never be rebuilt. If the YHWH admirers in Samaria are now to be understood as a specific expression "within a comprehensive spectrum of Jewish-Israelite religiosity"14 and as one of the two independent "Israel" denominations that existed in the Palestinian heartland during the post-exilic period, 15 a new perspective will also emerge for the New Testament Samaritan texts. ${ }^{16}$ From the hermeneutic perspective, the fact that the authors of the three Gospels mentioned knew, used, and quoted all the scriptures of the Old Testament must be considered. The majority of these writings are Judaic and Jerusalem-oriented or pro-Judaic, and their later layers and texts (even though in coded form) ${ }^{17}$ are marked by sharp criticism of the Samarian YHWH admirers and anti-Samaritan (foreigner) polemics. The fundamental orientation towards Jerusalem is thus also to be found in the three Gospels, as their authors are deeply rooted in Jewish-Christian traditions. ${ }^{18}$ Nevertheless, it is not clear whether and to what extent they also participated in the anti-Samaritan polemics of some writings and texts.

Consequently, in John, Matthew, and, above all, Luke-Acts, equal attention is paid to the reception of Old Testament texts as to their concepts of Israel. Certain Old Testament texts can be seen as the origin of a specific concept of "Israel" in the Gospels, as they can be seen as the origin of a specific Christology. Only from the Israel understanding of a writer can the Samaritan texts possibly be adequately opened up. The Gospel of Luke in particular, but also the Gospel of John, reveals that at the end of the 1st century A.D., at least in the Jewish-Christian area, despite a Jerusalem-focused perspective and some

7 See (Böhm 2012, pp. 182-88). (Hensel 2016, p. 413): “Mit Beginn der persischen Zeit und in einer gewissen Fortsetzung des Nebeneinanders von Süd- und Nordreich zu staatlicher Zeit [existierten] zwei selbständige (von einigen Berührungspunkten abgesehen), unterschiedlich konturierte, (mehrheitlich) monotheistische Jahwismen im palästinischen Kernland." This suggests not only the size of the sanctuary on the Gerizim, but also the prosperity of the Samaria region in post-exilic times. Hensel 2016, p. 413)

Cf. (Hensel 2016, pp. 257-389) to Sir 50:25-26; Jos Ant 11,297-347; 12,257-264; Esr, Neh, Chr, 2 Kgs 17:24-41.

(Hensel 2016, p. 415)

1 See (Schmid 2012, p. 31).

2 See ibid.

13 See (Hensel 2016, p. 5) for the post-exilic period: “Die Zahl der JHWH-Verehrer im Norden war vermutlich um einiges höher als jene der Judäer."

14 (Weingart 2014, p. 332).

15 (Hensel 2016, p. 413)

16 (Böhm 2012, pp. 198-202).

7 (Hensel 2016, p. 413)

18 This is now also true, with increasing consensus, for the author of Luke-Acts: cf. (Wolter 2008, pp. 9-10; Rusam 2008, pp. 194-95, 235). 
polemics transported from Old Testament writings, Samaria (as part of the former Northern Empire) was home to a population of YHWH-loyal and Torah-observant who belonged to Israel as the people of God but were critical of Jerusalem. ${ }^{19}$ Here, the New Testament reveals itself to be astonishingly less ideological, at least in two of these writings (Luke-Acts and John 4 ). ${ }^{20}$ It gives a surprising insight into a reality that is otherwise mostly concealed or only hinted at in the writings of the Old and the New Testament. ${ }^{21}$

Luke, John, and Matthew represent altogether different attitudes towards the Samaritans. Nevertheless, they represent opinions, which might also have been found in contemporary Judaism towards the Samaritans. Depending on the historical knowledge and ideology, the theological view of history, and the ecclesiological understanding of "Israel", the YHWH worshippers in Samaria could be classified as an integral part of the people of God or rather as non-Israelite.

Within the framework of historical and hermeneutical considerations, the Samaritan terminology used in the texts must also be reconsidered. The use of the Greek name $\Sigma \alpha \mu \alpha \rho \tilde{\tau} \tau \alpha \iota$ is extremely rare in the sources up to the 1st century A.D. It is certainly verifiably encountered only in Ptolemaic Egypt ${ }^{22}$ and, strictly speaking, is used as a designation for inhabitants of Samaria only in 2 Kgs 17:29/LXX. The Septuagint passage offers the oldest evidence. ${ }^{23}$ The 2nd Book of Kings was translated into Greek only later, probably only in the first half of the 2 nd century B.C. ${ }^{24} \Sigma \alpha \mu \alpha \rho \tilde{i} \tau \alpha \mathrm{l}$ is here the reproduction of the Hebrew Shomronim and refers from the context in 2 Kgs 17:24-41 to the Northern Israelites before 721 B.C. It definitely does not refer to the pagan colonists settled by the Assyrians in Samaria after 721 B.C., who after 17:24 and 17:30 also included settlers from the Cutha region and who according to the representation of $2 \mathrm{Kgs} 17$ represented the new population of the former Northern Empire.

Following chronologically, the next evidence for $\Sigma \alpha \mu \alpha \rho(\varepsilon) \tilde{\tau} \tau \alpha \iota$ after 2 Kgs 17:29/LXX are those

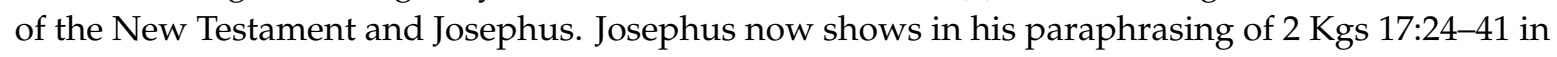
Ant 9,288-291 that the term $\Sigma \alpha \mu \alpha \rho(\varepsilon) \tilde{c} \tau \alpha$ l at the end of the 1st century A.D. could be polemically related to the population currently living in the former Northern Empire, ${ }^{25}$ as he now equates the

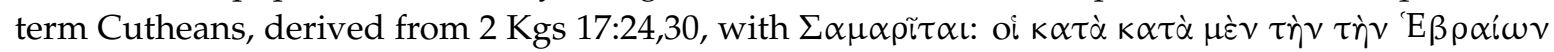

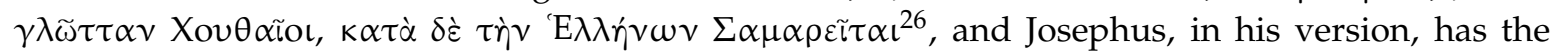
Gerizim community of his own time in mind. ${ }^{27}$ The context, which refers to religious practice, mixes $\Sigma \alpha \mu \alpha \rho \varepsilon i \tau \tau \alpha$ as both a designation of origin and a characterization as a religious grouping. Josephus' other uses of $\Sigma \alpha \mu \alpha \rho \tilde{\imath} \tau \alpha{ }^{28}$ must also be explored in context. He uses sources that refer to different epochs and times, but the result is above all his own view, which means nothing can be said about the use of the term $\Sigma \alpha \mu \alpha \rho(\varepsilon) \tilde{i} \tau \alpha \iota$ in his sources.

The New Testament texts stem from about the same time as Josephus, and similar to Josephus, they offer $\Sigma \alpha \mu \alpha \rho(\varepsilon) \tilde{i} \tau \alpha \iota$ as an external designation for a group that can be defined not only with regard to its origin, but also according to its religious characteristics. Was this the beginning of the designation $\Sigma \alpha \mu \alpha \rho(\varepsilon) \tilde{c} \tau \alpha \iota$ in this sense? Josephus presents us not only with the cult admirers of YHWH

19 See Lk 9:51-56; Lk 17:11-19; John 4:4-42.

20 Cf. chapter 2.2. and chapter 2.3. (see below).

21 See (Schmid 2012, p. 34), with reference to 2 Kgs 17:24-40; Ezra 4:1-5; Neh 13:28-30; 2 Chr 30:1-18. In the New Testament, Matt 10:5-6 is likely to be counted among them. See chapter 2.1 .

22 For the early period, there is only one certain piece of evidence for an ethnic group concerning Samaria, which offers the

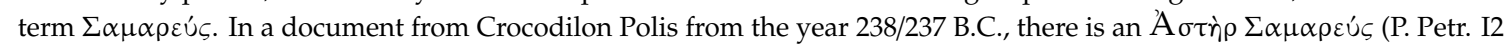
Col. III Z. 76), who is probably a settler (cleruch) from Samaria (Kuhs 1996, p. 29). All other mentions in the early papyri refer to inhabitants of the Egyptian village of Samareia. On the discussion see (Böhm 2018, pp. 177-80).

23 See (Hensel 2016, p. 369).

24 See (Kreuzer et al. 2011, p. 735).

25 (Hensel 2016, pp. 367-68).

26 Jos Ant 9,290. Cf. (Pummer 2009, pp. 676-80).

27 (Pummer 2009, pp. 75, 80).

28 Josephus provides a number of mentions, especially in the Jewish Antiquities: e.g., Jos Ant 11,84.88.97.116f. 174.340; $12,10.257 ; 18,30$. 
who are focused on Mount Gerizim, but also $\sum \alpha \mu \alpha \rho \tilde{\imath} \tau \alpha \iota$ also $\sum \alpha \mu \alpha \rho \varepsilon \tilde{\imath}{ }^{29}, \Sigma \iota \kappa \iota \mu \tilde{\imath} \tau \alpha /$ "Shechemites"30,

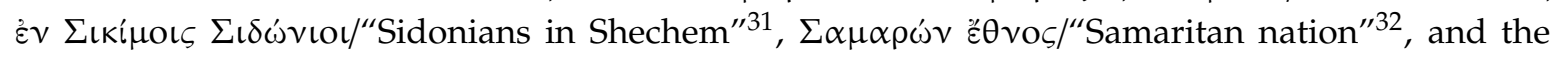

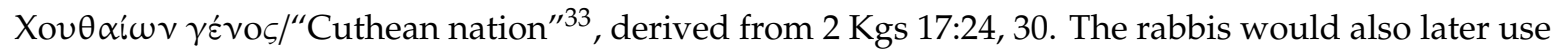

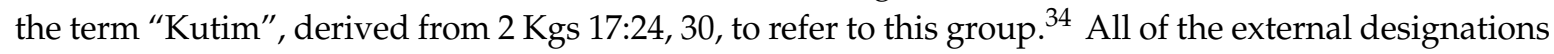
mentioned in the sources allude to aspects of origin, whereby the terms are suitable for different semantics-both neutral and pejorative, due to their relationship with descent and thus problematic religiosity—which can also overlap and mix. At least the case of "Kutim" is clearly trying to reinforce the idea of separation in its insinuations and ideologizations.

The variety of terms used by Josephus indicates that, until the end of the 1st century A.D., the terminology had not (yet) been uniformly and firmly established. The New Testament texts, on the other hand, offer only $\Sigma \alpha \mu \alpha \rho \tilde{i} \tau \alpha$ เ out of the whole spectrum of possibilities, varied only with one mention of $\varepsilon \theta v o \varsigma \tau \tilde{\eta} \varsigma \Sigma \alpha \mu \alpha \rho \varepsilon i \alpha \varsigma^{35}$. These designations are initially ideologically free-if we do not want to assume beforehand that they are influenced by an older tradition that may lie behind Jos. Ant 9,290. In principle, they focus on the whole region of Samaria and its population, not only on highlighted towns or villages and their inhabitants. Where $\Sigma \alpha \mu \alpha \rho i \tau \alpha \iota$ is used with religious implications to differentiate from 'Iov $\delta$ iol, it is a contemporary, but still young, Jewish language practice that was neither uniform nor firmly defined in itself.

Perhaps it can therefore also be understood as a late differentiation, made later during an increase in theological differences. The trigger for this could have been the further formation and implementation of a different basic concept of "Israel" on the part of the 'Iov $\delta \alpha$ ío. Constitutive in this is an eschatology focused on Jerusalem, the temple on Zion, and the Davidic dynasty through the emerging canon of the Torah, Nebeim, and Ketubim. Exclusive fixation on the Pentateuch ${ }^{36}$ and the theologoumena connected with it was now more and more difficult to tolerate. ${ }^{37}$ At this point, it can no longer be presumed that the previous compromise and consensus still held sway. Because the authors of the Gospel of Matthew, the Gospel of John, and Luke-Acts have their roots in Jewish-Christian traditions, they reflect a semantically young phenomenon when $\Sigma \alpha \mu \alpha \rho i \tilde{\tau} \alpha$ เ was understood beyond the ethnicon as a foreign term for a group religiously distinct from Judaism.

\subsection{Samaritans in Paul's Letters? Further Historical and Hermeneutical Questions}

These questions can therefore be extended to the Pauline letters as well, even if Paul does not speak at any point in his letters about people worshipping on Mount Gerizim. At the time of Paul, the term "Samaritan" had not yet been established to refer to the ethnically, but also religiously, defined group as mentioned in Section 1.1. From the perspective of religious history, the term "Samaritan" therefore represents an anachronism for the Pauline period as well as for the period before it. It was to be used only as a working title for the parts of the population of Palestine and the diaspora, for which Mount Gerizim was the center of the YHWH cult. ${ }^{38}$

\footnotetext{
Jos. Bell 2,232; 3,307; Ant 11,114; 13,74-75; 18,85.88; and others.

Jos. Ant $11,342.346 ; 12,10$.

Jos. Ant $12,257-262$.

Jos. Ant 18,85 .

Jos. Bell 1,63; Ant 13,255; Ant 11,19-20: Xov日 $\alpha$ íol.

See for example mNid 4,1; 7,3b-4b; mSheb 8,9b; mDem 3,4; bGit $45 a$.

Act 8:9.

See (Pummer 2009, p. 23): "For the Samaritans, Scripture means the Pentateuch."

The Samaritan Pentateuch represents a specific text that became current during the last two centuries B.C.E., which represents the original reading rather than the Masoretic text in some crucial places. The Gerizim commandment in the Decalogue is particularly striking. For an overview, see (Schorch 2012; Pummer 2009, pp. 23-27). Pummer concludes (see pp. 26-27), "In the second or first century B.C.E., the Samaritans made a small number of changes that reflect their ideology. What they evidently did was to choose one of the pre-Samaritan texts of the Pentateuch and modify it slightly in conformity with their beliefs and practices."

38 In the following, "Samaritans" and "Samaritan" are therefore placed in quotation marks wherever they appear from the time before 70 A.D.
} 
If the term "Samaritan" only first gained a religious connotation at the end of the 1st century A.D. to distinguish the group from the religious group 'Iov $\alpha$ ĩo (possibly as this only now became necessary), it raises the question of how the "Samaritans" were referred to before. If Paul had known of their existence, how would he have referred to them? According to the way the group understood and designated itself at the time of Paul, the term 'I $\sigma \rho \alpha \eta \lambda \tilde{\tau} \tau \alpha /$ "Israelites" should have been used, as can be proven in the eastern Mediterranean diaspora and in the geographical area in which Paul practiced his missionary activities. In 1979, two Greek inscriptions were found on the island Delos, which dated to approx. 250-175 B.C. and 150-50 B.C., in which "Samaritans" refer to themselves as "the Israelites who make contributions to the holy sanctuary Argarizein" and "the Israelites on Delos who make contributions to the sanctuary Argarizein" ${ }^{\prime \prime}$. The inscriptions are the only surviving self-designations from the Hellenistic-Roman period. ${ }^{40}$ They show that the founders saw themselves as Israelites, but also qualified themselves more closely in two respects: on the one hand, as Israelites on Delos and, on the other hand, as Israelites who orient themselves to the sanctuary on Mount Gerizim. ${ }^{41}$

Early external designations (before 70 A.D.) are also extremely rare and exist—if at all—only in the two versions of the book Ben Sira in chapter 50:25-26. ${ }^{42}$ The Hebrew version of the book Ben Sira, which dates from the time around 180 B.C., offers its translation of the relevant text as "the foolish people, that live in Shechem" ${ }^{\prime 43}$. The Greek version is dated after 129 B.C.; it offers in Sir 50:26

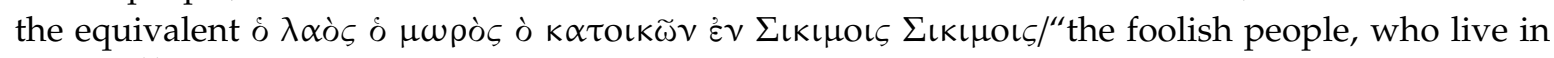
Sikima" $^{\prime 44}$. This designation corresponds with Jos. Ant 11,342.346; 12,10.12,257-262. One interpretation of the fact that there are almost no further or other external designations in the preserved literature before 70 A.D. suggests that the "Samaritans" were not yet perceived in religious terms as their own entity to be distinguished from Judaism until the late 1st century A.D. In this context, 2 Macc 5:22-23 (2nd century B.C.) is an interesting reference, because, here, it becomes clear that the people "in Jerusalem" and those "on the Gerizim" are also understood in Palestine to be one people by a Jewish author and that those "on the Gerizim" are counted among the Jewish people. ${ }^{45}$ One can assume that this was often the case, especially in the Diaspora, and that the Samaritans remained largely invisible in the early sources on the Diaspora, because their significant differentiation from Jewish groups lay "only" in the point of orientation to the place of worship, not in other joint principles of belief. This is probably also why they were included in the heterogeneous—also religious-Jewish spectrum. ${ }^{46}$

39 The English translations come from (Pummer 2016, pp. 93-94). There is also the Greek text. Both inscriptions were first published by (Bruneau 1982, pp. 467-75). However, their dating is not entirely certain. (Kartveit 2009, pp. 218-19) dates both inscriptions back to the first half of the 2 nd century B.C. on the basis of palaeographic features.

40 (Pummer 2009, pp. 16-17).

41 (Böhm 2012, pp. 189-98; Weingart 2014, p. 331). Cf. ibid. 332: Jewish and Samaritan YHWH followers can be understood here "als spezifische Ausprägungen innerhalb eines übergreifenden Spektrums jüdisch-israelitischer Religiosität".

42 Whether they actually refer to "Samaritans" is not certain. On this discussion, see (Pummer 2009, pp. 9-12).

43 The English translation comes from (Pummer 2009, p. 9) There is also the Hebrew text. The complete context in Sir 50:25-26 reads as follows: "Two nations my soul detests, and the third is not even a people: (26) Those who live in Seir, and the Philistines, and the foolish people that live in Shechem."

44 The Greek text in Sir 50:25 differs from the Hebrew version. The complete context here in English translation in Sir 50:25f is the following: "My soul was offended at two nations, and the third is not a nation: (26) those who settled on Mount Samaria and Philistiim, and the foolish people who live in Sikima" (For the translation and commentary on this passage, see (Pummer 2009, pp. 11-12).

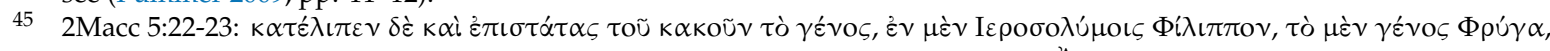

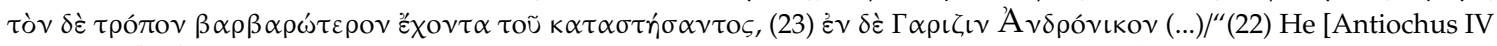
Epiphanes] left governors to oppress the people: at Jerusalem, Philip, by birth a Phrygian and in character more barbarous than the man who appointed him; (23) and at Gerizim, Andronicus (... )". For the discussion, see (Pummer 2009, pp. 12-13, 15). Interesting in this respect is also a later document from the 2nd century A.D. Justin (ca. 100-165 A.D.), who comes

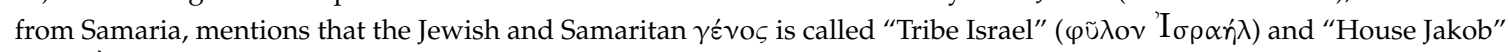

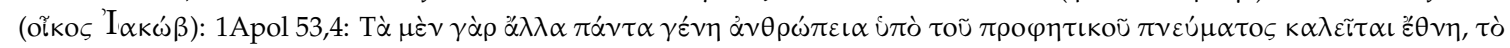

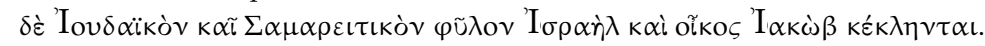

46 See (Böhm 2018, p. 188). 
This means that care must be taken when interpreting the term "Israel" and "Israelites" in the texts written before 70 A.D. ${ }^{47}$ This also applies to Paul, even if these terms certainly cannot claim any explicit meaning of their own. However, it also cannot be ruled out that the I I $\rho \alpha \eta \lambda \tilde{\imath} \tau \alpha \iota$ mentioned in the texts at least partly concerns those who were later named "Samaritans" and who were YHWH worshippers, counted themselves among Israel, and practiced circumcision. With these considerations, some Pauline texts may be read with different eyes: When Paul speaks of "Israel", "Israelites" and "circumcision", he could have consciously—as a precaution or out of real knowledge - used inclusive terminology that, in principle, included the "Samaritans" in the diaspora, even if they de facto did not exist locally. Even if in the Pauline epistles it sometimes sounds as if the world for Paul basically consisted only of "Jews" and "Gentiles" (i.e., "Greeks") ${ }^{48}$, Phil 3:1b-11 and 2 Cor 11:16-33 in particular could show that this was schematically not the case. Paul knew very well where it was necessary to differentiate. ${ }^{49} \mathrm{~A}$ critical look at these passages shows that they can only be reconciled with the category "Judaism" if one looks from the outside and determines the category "Judaism" on the basis of some Jewish identifying characteristics. However, from the internal perspective of the texts, if one orients oneself only by the terms contained in the text, one could also come to other categories-e.g., "Israel" or "Israelites", "those under the law", "Hebrews", and also "circumcision". If all source-language terms are not identified with "Jews" and "Judaism" from the outset, a different perspective may actually emerge.

It would therefore be worthwhile and help expand our understanding of the colorful religious reality of the 1st century A.D. if, for example, the mentions of 'I $\sigma \rho \alpha \dot{\eta} \lambda$, 'I $\sigma \rho \alpha \eta \lambda \tilde{i} \tau \alpha \iota$, E $\beta \rho \alpha \tilde{i}$, and $\sigma \pi \varepsilon \dot{\varepsilon} \rho \alpha \Lambda \beta \beta \rho \alpha \dot{\mu} \mu$ were specifically re-examined. ${ }^{50}$ Moreover, 1Cor 9:20-21 deserves (new) attention, because the passage can also be read in such a way that Paul consciously distinguishes

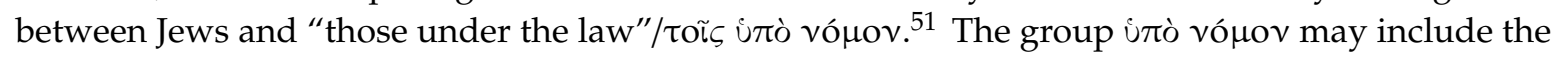
'Iov $\delta$ íol, but may extend beyond them. Paul would then capture various groups that see themselves under the law with this expression. ${ }^{52}$ Already in the Patristic Period, the opinion was expressed that one can associate the írò vó $\mu$ ov in 1Cor 9:20 to the Samaritans. ${ }^{53}$ Additionally, the Pauline speech of $\pi \varepsilon \rho \iota \tau o \mu \eta \dot{~ " c i r c u m c i s i o n " ~ a n d ~} \alpha \kappa \rho о \beta v \sigma \tau i \alpha$ "uncircumcized" could in some contexts possibly be a comparable case of deliberately taking broader categories. ${ }^{54}$ Then, the famous Jerusalem agreement of

47 See (Böhm 2012).

48 See Rom 2:9-10; 10:12; Gal 2:7-10; 3:28.

49 The fact that both sections of the letter, Phil 3:1b-11 and 2Cor 11:16-33, may be integrated fragments of originally independent writings from a literary-critical perspective makes the question even more exciting.

50 Cf. Phil 3:1b-11; 2Cor 11:16-33.

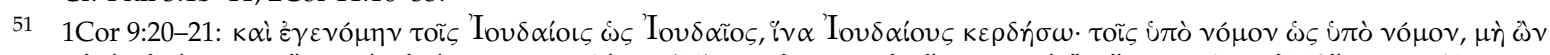

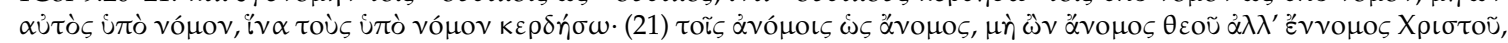

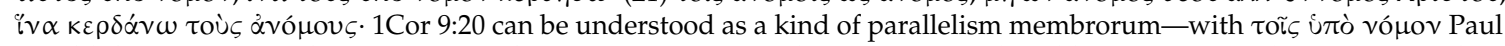
would then once again have an eye on the Jews just mentioned. In agreement (Merklein 2000, p. 230): “'Die unter dem Gesetz' meint die Juden in ihrer-von Christus absehenden—Selbstsicht und Selbstdefinition, d.h. die Juden, denen Paulus das Evangelium verkündigte. Diesen Juden wurde Paulus 'wie einer unter dem Gesetz'”. Or Paul speaks of a second group, that is more probable from the formal structure of the verses. See (Lindemann 2000, p. 212): " ... vom Textaufbau her wahrscheinlicher, da in V. 21.22a jedenfalls kein Parallelismus vorliegt." Lindemann suspects the second group contains "möglicherweise betont toratreue Juden oder auch 'judaisierende' Christen" (ibid.).

52 That would be plausible in so far as Paul in 1Cor 9:21 also avoids the categories "E $\lambda \lambda \eta v \varepsilon \varsigma$ and $\varepsilon$ " $\theta \vee \eta$, which are otherwise listed more frequently in his letters. In addition, with ă $v 0 \mu \mathrm{ol}$, he chooses a term that offered the greatest possible space for a

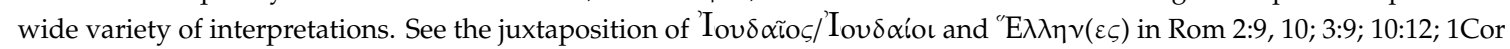

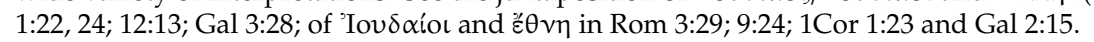

53 Origínes, Commentary on the Gospel of John, on John 8:48 (Greek text quoted from (Pummer 2002, pp. 72-75): 'A $\lambda \lambda$ o $\varsigma$

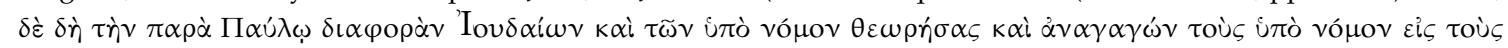

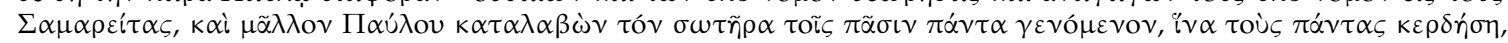

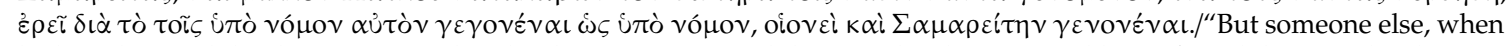
he has observed the distinction Paul makes between Jews and those under the Law, and has referred those under the Law anagogically to the Samaritans, and has understood that the Savior, more than Paul, became all things to all men that he might gain all men, will say that because he became as one under the Law for those under the Law, he also became a Samaritan, as it were, and in accordance with this he did not deny that he was a Samaritan."

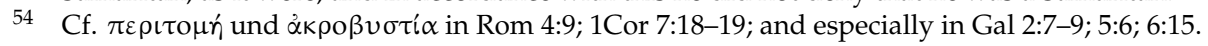




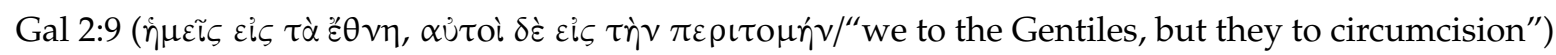
is possibly granted an extended dimension.

\section{The Classical Samaritan Texts of the New Testament in the Context of the Particular Israel Concepts and Christologies}

\subsection{Matthew (Matt 10:5-6)}

In Matthew, Jesus is the Son of God, Davidic Messiah, and shepherd of Israel, who makes a clear point of seeking out the lost sheep of God's people. ${ }^{55}$ Matthew restricts the earthly work of Jesus strictly and emphatically to Israel, ${ }^{56}$ but also connects it from the beginning to the end of the Gospel and the fulfillment of the hope of salvation for all nations. ${ }^{57}$

The logion in Matt 10:5-6, consisting of two prohibitions ( $v$ 5) and one commandment (v 6), could already have originated from pre-Matthean tradition ${ }^{58}$ but was most likely formulated by the author and set at the beginning of the missionary discourse. ${ }^{59}$ What he is looking to formulate here is important to him, in any case; it is about setting the scope of the disciple mission: like Jesus himself, the disciples before Easter should also turn exclusively to Israel. ${ }^{60}$ The structure of the verse gives space to different interpretations with regard to $\Sigma \alpha \mu \alpha \rho \tilde{\tau} \tau \alpha$ l. If a synonymous parallelism is intended in Matt 10:5b, Matthew equates the Samaritans with the nations of the Gentiles. However, if a synthetic parallelism is meant, Matthew sees the Samaritans as existing between the nations of the Gentiles and the lost sheep of the House of Israel. There are two further possible interpretations: The Samaritans are among the sheep of the house of Israel but not among those who are lost. ${ }^{61} \mathrm{Or}$-and this is more likely-Matthew reflects the impression of the time of Jesus that the Samaritans would not have been open to a Davidic Messiah as shepherd of Israel and that it was not yet the right time for the Samaria mission. ${ }^{62}$ The Samaritans had no theological reference to Jewish prophecy and to the Zion and Davidic traditions, but were fixated only on the writings of Moses in the special form of the Samaritan Pentateuch. It justified for them not only the cultic priority of the Gerizim, but also an eschatology focused on Moses. ${ }^{63}$

Under this assumption, Matt 10:5 could provide a historically accurate knowledge of the Samaritans that was not influenced by literary polemics. This thesis is supported by the use of tense in Matt 10:5-6. The two prohibitions use aorist forms ( $\dot{\alpha} \pi \dot{\varepsilon} \lambda \theta \eta \tau \varepsilon$ and $\varepsilon^{i} \sigma \dot{\varepsilon} \lambda \theta \eta \tau \varepsilon$ ), while the commandment to go to the lost sheep of the house of Israel is formulated in the imperative present tense. ${ }^{64}$ Consequently, the instructions for the twelve disciples are to be understood as something unique from the beginning, which in the context of the Gospel of Matthew, is related to the current state of Jesus' messianic ministry, while the sending of the disciples to the house of Israel becomes a permanent task for them. ${ }^{65}$ Under this assumption, Matthew would have been thinking of limiting the pre-Easter mission to Galilee. The prohibitions would then either have to be related to purely geographically determined areas in the vicinity of the Galilee region ${ }^{66}$ or that Matthew was actually (also) reflecting that the Samaritan

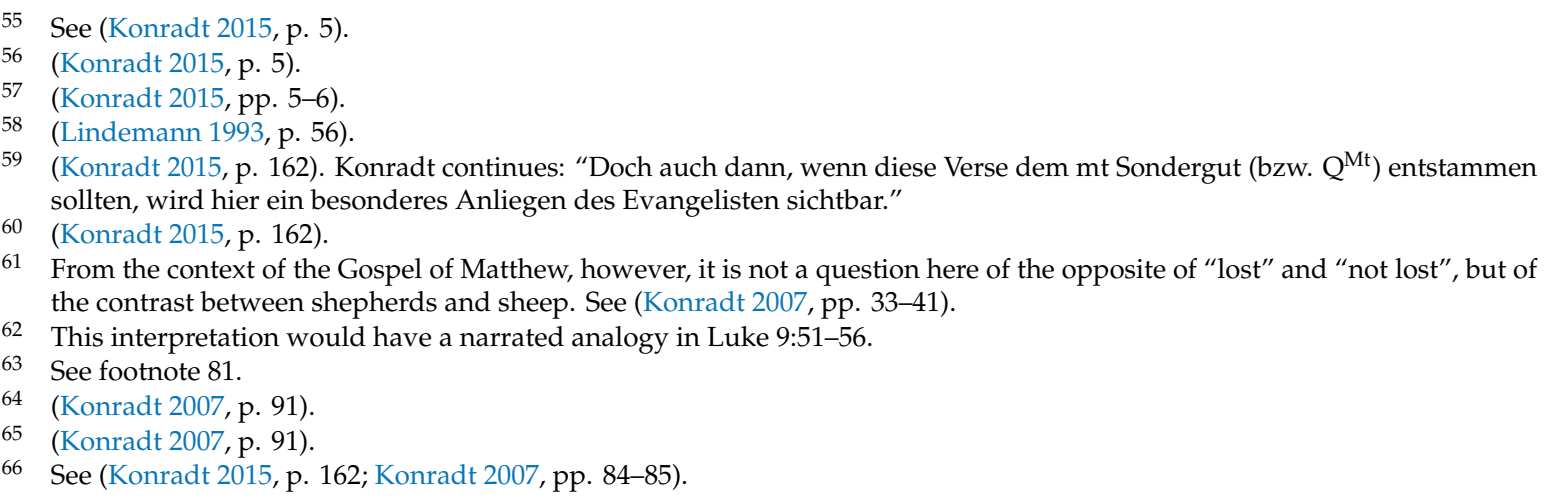


mission at the time of the historical Jesus had not yet succeeded (or had not been intended by him) ${ }^{67}$, but was only successful after Easter. On this point, he concurs with the depiction of Luke. ${ }^{68}$ Within the Gospel of Matthew, it fits that the itinerary does not lead through Samaria. Matthew even changed Mark's version here, thus ruling out the possibility that Jesus might have passed through what was politically understood as Judea, to which Samaria belonged. ${ }^{69}$ The final scene of the gospel in Matt 28:16-20 is again located in Galilee. Now, the post-Easter order is given to missionize among all nations. This order goes back to Matt 10:6; yet, in Matt 10:6, the Samaritans were not counted among the nations $(\tau \dot{\alpha} \varepsilon \theta v \eta)$. The question is the following: were they, for Matthew, among the lost sheep of the house of Israel, which now (like others in the Diaspora) also had to be reached, or was this a temporal matter-they could only now be reached, but then, were they successfully reached?

If Matt 10:5-6, on the other hand, is to be understood as a religiously defined demarcation, Matthew does not see the Samaritans as belonging to Israel. Because he refers only to the cities of the Samaritans, in this case, he might be influenced by the historical picture of 2Kings 17:24-41/LXX. This means that he is sharing a literarily transmitted view of the cities in the southern neighboring region of Galilee that is widespread in contemporary Judaism. According to 2Kings 17:24-41, descendants of foreign colonists lived in the cities of Samaria ${ }^{70}$, people who had been taught in the YHWH cult but still practiced syncretism—and that "to this day" (2Kings 17:41).

\subsection{The Samarian and Samaritan Texts in Luke-Acts}

In Luke, as well, Jesus is the Son of God and Davidic Messiah King of Israel, and the promises of the people of God in Jesus Christ are fulfilled by involving the nations of the Gentiles in salvation. ${ }^{71}$ One of the background texts for the entire theological conception of Luke-Acts is the three-stage promise text in Isa 49:6/LXX. ${ }^{72}$ The prophetic promise in Isa 49:6 sets out a program in which three interlocking eschatological expectations are to be fulfilled: the twelve tribes of the people of God Israel are to be gathered, those scattered into the diaspora are to be brought back, and the nations of the Gentiles are to be included in the salvation of Israel. ${ }^{73}$ Luke-Acts is designed in such a way that the earthly and then the exalted Christ and Son of God brings these three promises to fulfillment. Jesus himself collects the people of God Israel by bringing together the house of Jacob during his earthly activity. This is the first stage of fulfilling the promises described in the Gospel of Luke. This also explains why in Luke, Jesus only turns to the people of God Israel in Palestine and does not cross the borders of the Jewish territory (in contrast to Mark and Matthew). The presentation of Acts, on the other hand, shows the way beyond Jerusalem, Judea, and Samaria into the Diaspora and the inclusion

67 According to (Meier 2000, p. 221).

68 See Section 2.2.

69 According to Matt 19:1, Jesus departs Galilee and comes to the border region of Judea beyond the Jordan ( $\varepsilon \dot{\zeta} \varsigma \tau \grave{\alpha}$ ö $\rho\llcorner\alpha \tau \tilde{\eta} \varsigma$

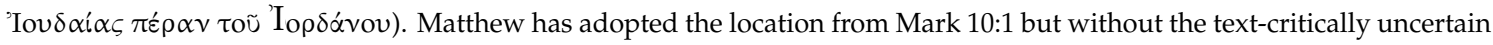

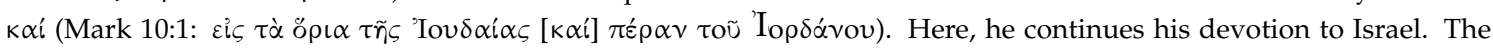
location is peculiar and controversial in its meaning: (Luz 2012, p. 92; Fiedler 2006, p. 308). If it is a matter of determining a route (Luz 2012, p. 92), this one leads along the other side of the Jordan through a border area populated by Jews. From Matt 20:17, Jesus goes up to Jerusalem; in Matt 20:29, he leaves Jericho.

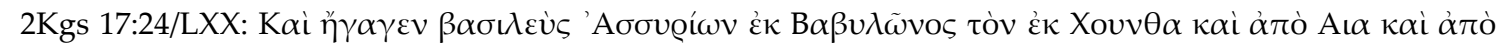

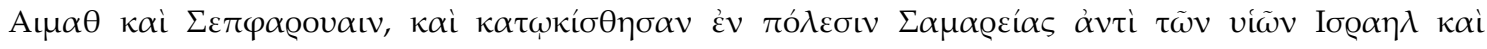

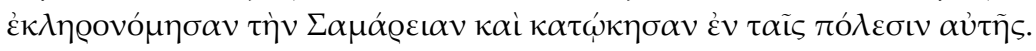

71 However, there are several differing Christological concepts in Luke. See (Jantsch 2017, pp. 335-41).

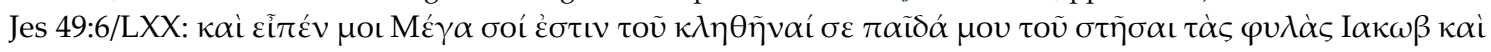

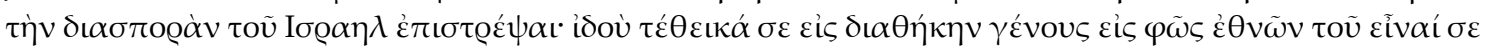

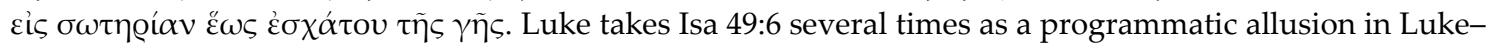
Acts: Luke 2:30-34; Act 1:6-8; Act 13:47. See (Böhm 1999, pp. 186-91).

73 The theme of Israel's restoration has been prominent in recent studies of Luke-Acts. See (Bauckham 2008, p. 327). 
of the Gentiles in salvation. ${ }^{74}$. This overall concept also incorporates the Samaritan and Samaria texts of Luke-Acts, of which only Luke 9:51-56 can be discussed as a detailed example in this framework. In my opinion, all three texts reveal more detailed knowledge about the Samaritans and the relationship between Jews and Samaritans in the 1st century A.D. ${ }^{75}$

The three Samaritan texts of the Gospel of Luke (Luke 9:51-56; 10:25-37; 17:11-19) are special traditions whose origin is no longer known. ${ }^{76}$ They belong in the so-called Luke's travelogue (Luke 9:51-19:27), which takes place between the ministry of Jesus in Galilee (Luke 4:14-9:50) and Jesus' ministry in Jerusalem from Luke 19:28 onwards. Until Luke 9:50, the Son of God and Messiah of Israel healed and preached in Galilee. ${ }^{77}$ In the Gospel of Luke, Jesus first makes his way to a Samaritan

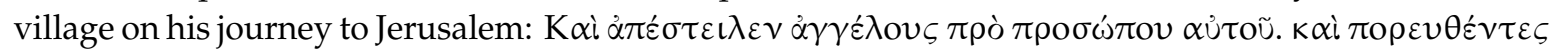

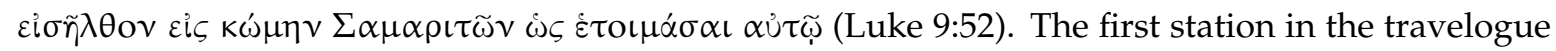
shows that, for Luke, the Samaritans belong fundamentally to the messianic mission of Jesus to gather and restitute the people of the God of Israel. However, the Samaritans reject the request for accommodation in Luke 9:53. According to the narrative, the request is not rejected because they are

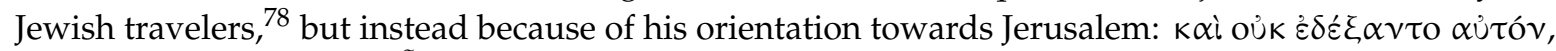

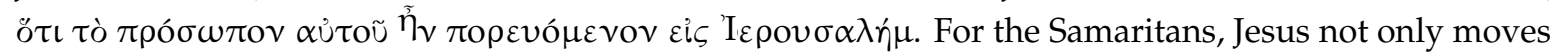
to the wrong place of worship, ${ }^{79}$ but-and this is related-also to the wrong location of eschatological hopes. Because the gathering of Israel initiated by Jesus takes place under the target of Jerusalem, it is rejected at the narrative level. From this point of view, and to my knowledge, this has so far never been considered-the request for accommodation in Samaria at the narrative level was, as I see it, strategic and well prepared. In the story of the Transfiguration in Luke 9:35, Jesus on the mountain is identified with the prophet like Moses by the allusion to Deut 18:15/LXX with the voice of God in the cloud.$^{80}$ With this, he fulfills the decisive eschatological expectation of the Samaritans, who were fixated only on the Pentateuch. ${ }^{81}$ It is not only in the story of the transfiguration that Luke's Jesus is repeatedly depicted using Moses motifs. ${ }^{82}$ Even though Moses redivivus is a broader Jewish hope, Luke's allusion to Deut 18 in Luke 9:35 may have been designed in preparation for the journey through Samaria. Thus, the fulfillment of a (decisive) promise is implied, ${ }^{83}$ a hope, which for the Samaritans was the only acceptable one from the spectrum of eschatological hopes, but with no connection to Jerusalem. At the narrative level, it is impossible to know that Moses (sic!) and Elijah had said to Jesus on the Mount of Transfiguration that his end should come to pass in Jerusalem (Luke 9:31). ${ }^{84}$

Significantly, Luke tells us in Act 8:4-25 that the Samaria mission was a great success after Easter. ${ }^{85}$ In the chronological outline of Acts, this success lies in the time in which the Jerusalem Temple

74 (Böhm 1999, pp. 186-91).

75 For the arguments for each individual text, see (Böhm 1999; Wolter 2008, pp. 396, 398, 573). Cf. (Frey 2012, pp. 211-15). Frey emphasizes, however, that Luke is not really concerned with the Samaritans as such (215), but rather with a counterimage to the Jewish religion, especially to its functionaries, and with a paradigm for overcoming religious-ethnic barriers based on following Jesus and listening to his word.

76 Though Luke had access to Jesus traditions, which are otherwise no longer accessible (cf. Act 20:35).

77 (Bovon 1996, p. 23).

78 At the beginning of the 1st century A.D. Jesus, as presented by Luke, can ask for accommodation in a village of Samaria without conflicting with the purity regulations; these were obviously observed in Samaria as well as in Galilee and Judea.

79 Cf. (Frey 2012, p. 211; Wolter 2008, p. 370; Lindemann 1993, p. 58).

80 (Wolter 2008, p. 354). Cf. Act 3:22

81 The expectation of Moses redivivus results from the focus on the Pentateuch. In the Samaritan Pentateuch, Deut 18:18-22 was appended to the Decalogue in Ex 20:21b (in its form extended by the Gerizim commandment). Thus, the expectation of Moses redivivus was related to the Gerizim. Jos Ant 18,85 indicates that eschatological expectations for the Gerizim already existed in the 1st century A.D., at the time of Pilate. Cf. (Pummer 2016, pp. 62-63).

82 Lk 4:18-21; 6:17; Act 3:22; (Sellner 2007, pp. 82-88).

83 Luke appreciates the prophet's motive and applies it to Jesus, but it cannot be unambiguously assigned to a certain end-time prophetic expectation of early Judaism. "In seinem Bemühen um die prophetische Darstellung der Gestalt Jesu bedient sich Lukas aus dem Motivinventar des 'Propheten wie Mose', ohne dabei Elemente der Elia/Elischa-Motivik zu verleugnen" (Sellner 2007, p. 88).

84 Luke has inserted the passage beyond Mark 9: 4-5.

85 Cf. Act 9:31; 15:3. 
became less important for a part of the faithful in Christ, to whom also the Samarian missionary Philip belonged. ${ }^{86}$ The emergence of a Samaritan Christianity might thus have significantly benefited from the fact that, in parts of the early Christian preaching, the Jerusalem temple and any other man-made structure are critically evaluated as a place for the worship of God. ${ }^{87}$ Luke suggests that the post-Easter gathering of the people of God in Samaria became possible because the missionaries on behalf of the Risen Lord (Act 1:8) changed direction, away from Jerusalem towards the Samaritans. At this point, the Samaritans show an open attitude on the narrative level and receive the message. ${ }^{88}$

Back again to Luke 9:51-56: what happens after the rejection of Jesus in the narrative in Luke 9:53-56 is indicative of the general helplessness in dealing with the religious conflict between the two groups, which had smoldered beneath the surface, and with regard to cultic matters, had grown since Hasmonaean times. The disciples were incensed by the Samaritan's rejection of Jesus and invoke the name God through Elijah's words in 2 Kings 1:10-14 to remedy their comparably weaker position on foreign soil, to stage a miracle of punishment through his power (Luke 9:54). In so doing, the intent to cause physical harm to the Samaritans is part of the plan from the outset: fire is to consume them and their village.

However, their focus on the Pentateuch meant that the Samaritans did not recognize the prophetic sign as such and therefore did not acknowledge it. ${ }^{89}$ Jesus can also not offer any meaningful solution in terms of further discussions with the Samaritan villagers: the Gospel simply states, "The Lord turned around and rebuked them" (Luke 9:55).${ }^{90}$ Thus, the disciples are forced to rethink the actual will of God and possibly also the special conditions in a Samaritan village. ${ }^{91}$ Escalation of the conflict was prevented. However, given the villagers' rejection, Jesus also failed, and leaves them in peace. ${ }^{92}$ At the end of the short story, it says: "Jesus and the disciples went to another village" (Luke 9:56). ${ }^{93}$

Luke 9:51-56 was, to a certain extent, a repetition of what happened in Nazareth in Galilee ${ }^{94}$ : the Savior of Israel, the fulfillment of all promises, experiences rejection and conflict within the central regions of Palestine where the people of God live. ${ }^{95}$ The same can be said for Jerusalem, i.e., also in Judea $^{96}$. Whether the other village to which Jesus and the disciples moved was also intended to be a Samaritan village is unknown. ${ }^{97}$ Even if it were a Samaritan village, there is no record of such visit.

The request to stay with Samaritans, quite apart from the primarily theological significance of this stop for Luke, shows that, despite the difficult common history, there was a community of convenience, as neighbors perhaps, between Jews and Samaritans. Galilean pilgrims could apparently travel to Jerusalem through Samaria. ${ }^{98}$ This short story could be a reflex of a memory that the historical Jesus, with his message and understanding of his own mission, could not gain a foothold with the Samaritans. ${ }^{99}$ That Jesus would be unable to complete his mission, to bring together all people of the God of Israel, oriented towards Jerusalem, even seems historically plausible. ${ }^{100}$

\footnotetext{
Act 6:13; 7:48-50. Cf. (Böhm 2002, p. 116).

(Böhm 2017, p. 359).

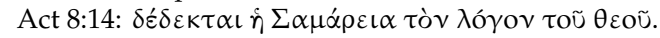

One can at least consider whether the disciples also needed such a rebuke.

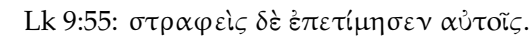

1 See (Bovon 1996, pp. 27-28): “Der Heilsplan Gottes verwirklicht sich aber nicht durch Gewalt, ( . . ) sondern durch Schwachheit, d.h. im Annehmen von Scheitern, von Leiden, von Begrenztheit."

92 (Böhm 2002, pp. 117-18).

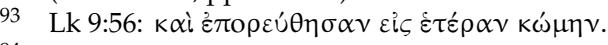

4 Lk 4:16-30.

95 The preparations of the disciples in Luke 9:51 do not only concern accommodation, but also the coming and proclamation of Jesus.

96 Lk 19:47. Cf. (Bovon 1996, p. 25): "Symmetrisch zur Verwerfung Jesu in Nazaret (Lk 4,29-30) nimmt das Ereignis in Samarien das fatale Ende der Reise nach Jerusalem vorweg."

97 Cf. (Bovon 1996, p. 28). For another perspective see (Frey 2012, p. 211).

98 Cf. Jos Vit 268-270.317ff; Joh 4:4. Cf. (Frey 2012, p. 221).

99 Cf. (Bovon 1996, p. 24): “Die Erzählung ( . . ) hat also einen archaischen Kern; sie ist mehr als eine nachösterliche Projektion ins Leben Jesu."

100 (Böhm 2017, p. 358).
} 
The short fictional story of the Good Samaritan (Luke 10:30-35), which is put into context by Luke 10:25-37, also picks up the difference of cultic places between Jews and Samaritans, ${ }^{101}$ but in a very subtle way. ${ }^{102}$ The Samaritan represents the other part of Israel and is a counter-figure to the priest and Levite, who, as cult officials on the narrative level, invoke the most important difference between the two groups. The Samaritan provides an exemplary demonstration that the interpretation of the most important commandments of God among the people of God does not depend on the place of worship (the priest and the Levite were returning from Jerusalem and thus presumably temple service). Instead, it should be based on God's love and, as it were, on the streets and in everyday life, on the attention given to those in need. ${ }^{103}$ Thus the Samaritan proves to be a better interpreter of the will of God, a true Israelite and also one who need not worry about the initial question posed by the

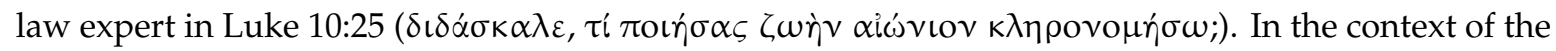
Gospel of Luke, the example story hints at Jesus' continuing positive attitude towards the non-Jewish portion of God's people, even after being rejected by a Samaritan village (Luke 9:51-56). In return, in Luke 17:11-19, a Samaritan, unlike the Jewish members of the group of healed lepers, shows the appropriate attitude towards Jesus, recognizing that this person is the right place for giving thanks and worship of God. That he is referred to as $\dot{\alpha} \lambda \lambda$ o $\gamma \varepsilon \vee \eta \dot{\zeta}$ (Luke 17:18) can be seen as an ironic allusion. Since Hasmonaean times, "foreigners" became more and more a polemic label for "Samaritans". ${ }^{104}$ The story also relativizes the significance of the two different places of worship for Jews and Samaritans. It points to the new, eschatological place of worship for both parts of the people of the God of Israel: Jesus Christ. ${ }^{105}$

\subsection{John (John 4:4-42; 8:48)}

The alternative Christ-based eschatological concept of worship of God, which integrated all groups within the people of the God of Israel (and beyond), is also found in the story in John 4:4-42, which is strongly influenced by John's theology. The story is part of the narrative running through John 2-4, which presents the sum of eschatological Israel. ${ }^{106}$ Before this, the author had described Jesus as the Messiah (John 1:41) and then described him as the one about whom Moses had written in the law and of whom the prophets had also foretold. ${ }^{107}$ It is only here that the Gospel of John explicitly mentions the triad of Moses, the law, and the prophets. ${ }^{108}$ We cannot rule out that this was intended to bring together the prophetic expectations of Deut 18:15, 18 ${ }^{109}$, and those of the royal Messiah are brought together here. ${ }^{110}$ Thus, all the significant texts are named, but in a way that also anchors all their eschatological concepts on one person. ${ }^{111}$ In John 1:47, Nathanael is identified as a true Israelite and ideal representative of the people of God, for he comes to Jesus, sees, and overcomes his skepticism. ${ }^{112}$ Although Jesus of Nazareth does not fulfill a traditional idea from Scripture for Nathanael, ${ }^{113}$ he subsequently calls Jesus the Son of God and King of Israel (1:49). The Nathanael scene is also decisive for the Samaritan narrative in John 4. Jesus is the salvific figure for Israel described in

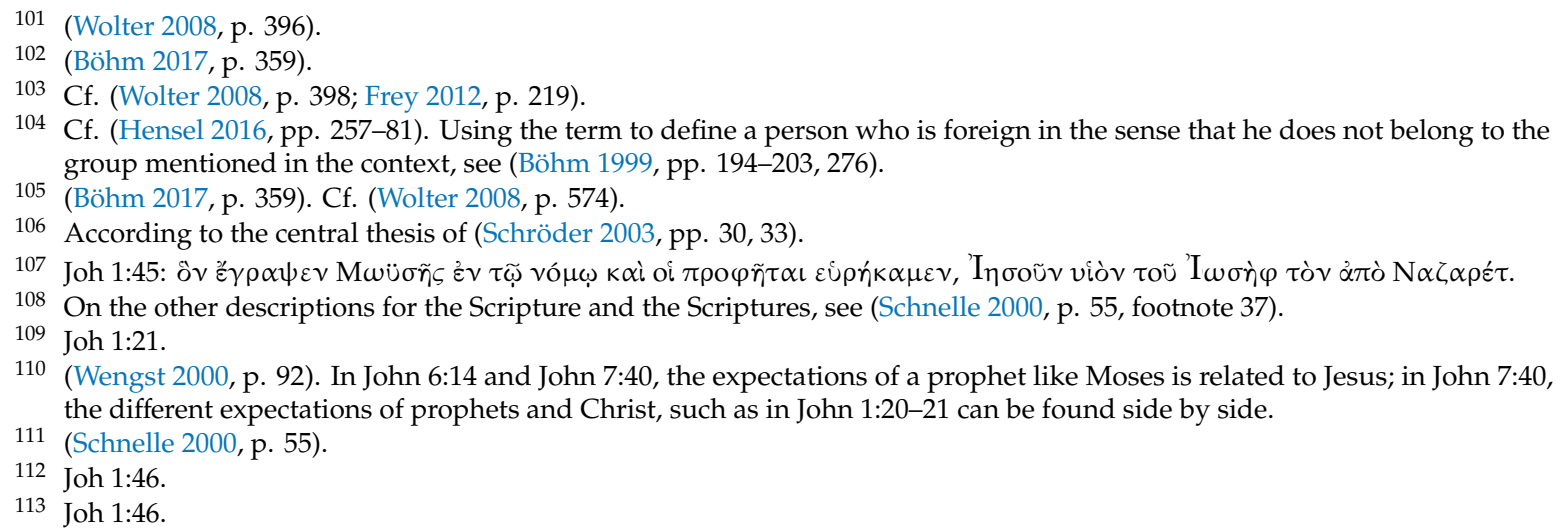


all scriptures, although he does not fulfill all of the traditional expectations. The affront to expectation can only be overcome by meeting him in person.

In John 4:4, Jesus goes to Samaria, and here too, there is confusion as previous beliefs are crushed. In essence, however, it is now a matter of the various places of worship and the true worship of God associated with them. John 4:20 proclaims the definitive theological criterion of difference between Jews and Samaritans as the belief in their own, different but central place of worship of God. ${ }^{114}$ Jesus himself

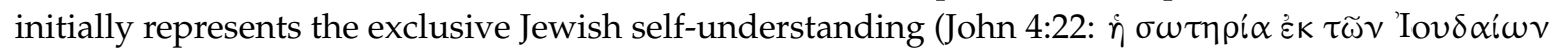
$\dot{\varepsilon} \sigma \tau(i)$ ), but then introduces a new concept of worship of God that will relativize the different cult places that had previously existed, ${ }^{115}$ that of worship of God marked by spirit and truth, ${ }^{116}$ which, in this respect, means eschatological fulfillment. ${ }^{117}$ In the course of the conversation, Jesus proves himself to be the one who fulfills these eschatological expectations within the framework of a self-revelation. ${ }^{118}$ Alternatively, one can discuss if the Messiah concept is opened to expansion and is now malleable to Samaritan expectations. ${ }^{119}$ However, where the worship of the God of Israel takes place in faith in Jesus, the community of his admirers is united—and detached from any place of worship. ${ }^{120}$

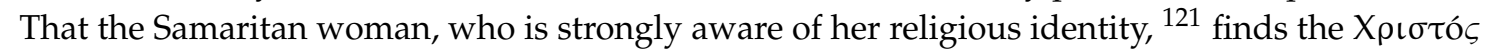
in Jesus ${ }^{122}$ remains strange in this narrative, because the figure of hope on which the Samaritan eschatology is focused in New Testament times was "the prophet like Moses", promised in Deut 18:18. ${ }^{123}$ In my opinion, the Messiah title should be taken seriously here, even where this leaves questions open for further discussion. Is the Jewish Messiah concept, understood in a certain way

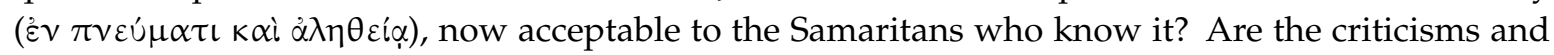
rejection of the Jewish Messiah concept now overcome for the Samaritans in their physical encounter with Jesus? Jesus reacts to the knowledge of the Messiah in John 4:26 with an I-am-word. With this, he reveals himself by means of association with Ex 3:14 as a savior figure for the last days and the Messiah. That this happens to the Samaritan woman with an allusion to the central self-conception of God against the ideas of Moses from the Pentateuch could in turn unite these different traditions in his person. At the end of the story, Jesus won over many Samaritans with the offer of salvation associated with him. Significantly, however, they do not all proclaim him as Messiah, but as "Savior of the World". ${ }^{124}$ In so doing, they are not only firstly relativizing their place of worship of God legitimized by tradition and the eschatological concepts associated with it, but also other places and ideas, and within the worship of the God of Israel, they are also the first to adopt a universal perspective.

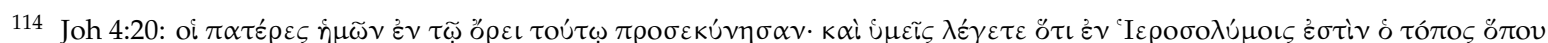
$\pi \rho 0 \sigma \kappa \cup \vee \varepsilon \tilde{\imath} \delta \varepsilon \tilde{\iota}$.

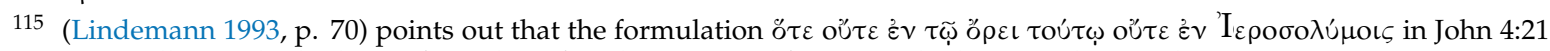
practically puts both places of worship of God on an equal footing and relativizes them in the same way.

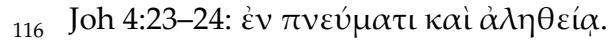

117 (Frey 2012, p. 228).

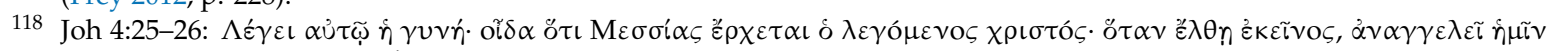

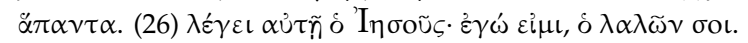

119 For this consideration, I would like to thank one of my colleagues, who reviewed this article.

120 (Frey 2012, p. 229).

121 (Frey 2012, p. 222): "eine traditionsbewusste Angehörige der Garizimgemeinde".

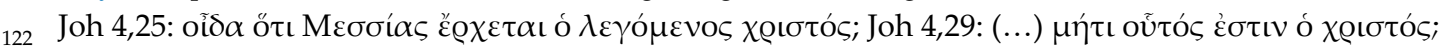

123 (Frey 2012, p. 229): “Damit ist ihr Bekenntnis ,judaisiert' oder einfach in johanneischer Sprache gestaltet." That the expectation of the Taheb developed from Deut 18:15, 18 and found in the later Samaritan sources (4th century and later) appears here, clothed in the speech of the coming of the Messiah that is more understandable for Jews and Christians, has been discussed again and again: See (Lindemann 1993, pp. 70-71; Meier 2000, p. 230; Pummer 2009, p. 361; Schröder 2003, pp. 162-63).

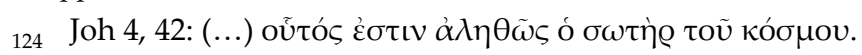


In the second text of the Gospel of John, in John 8:48, Jewish opponents of Jesus accuse him of being one of these crazy Samaritans, ${ }^{125}$ because he questions their claim to salvation traditions and thus their relationship to God. This identification insinuates an existing theological affinity between Jesus and the Samaritans and reveals the dissent between Jews and Samaritans, shaped by polemics, with regard to the traditions of the fathers. As in John 4:4-42, the dissent in John's mind is overcome in John 8:58 by Jesus' claim not to be subject to temporal limits, to have existed before the ancient forefathers, and to be the place of divine revelation in history. ${ }^{126}$ In this respect, in John's mind, all the fundamental separations between the people of God are unified in Jesus in John's mind.

We must therefore consider that all Samaritan texts in the New Testament are based on a historically correct knowledge of the cult of YHWH worshippers in Samaria oriented towards the Gerizim. Viewing all texts in the context of its own Israel ideas and Christology, the Samaritans occasionally appear implicitly stronger and are more often considered in the representations of the Gospels than would be first thought.

However, further and more in-depth studies beyond the observations presented above are necessary, among other things, on the juxtaposition of prophets' expectation according to Deut 18:15, 18 and the Messiah concept. They will probably not provide any conclusive evidence for a conscious (background) inclusion of significant Samaritan theologumena, but it might be worth playing through such possibilities in principle to question their plausibility.

Funding: This research received no external funding.

Conflicts of Interest: The author declares no conflicts of interest.

\section{References}

Bauckham, Richard. 2008. The Restoration of Israel in Luke-Acts. In The Jewish World around the New Testament. Wissenschaftliche Untersuchungen zum Neuen Testament 233. Edited by Richard Bauckham. Tübingen: Mohr Siebeck, pp. 325-70.

Böhm, Martina. 1999. Samarien und die Samaritai bei Lukas. Eine Studie zum religionshistorischen und traditionsgeschichtlichen Hintergrund der lukanischen Samarientexte und zu deren topographischer Verhaftung. Wissenschaftliche Untersuchungen zum Neuen Testament II/111. Tübingen: Mohr Siebeck.

Böhm, Martina. 2002. “Und sie nahmen ihn nicht auf, weil sein Gesicht nach Jerusalem zu ging” (Lk 9,53). Samaritaner und Juden zwischen dem 4. Jh. v. und 1. Jh. n. Chr. In Regionale Systeme koexistierender Religionsgemeinschaften. Hallesche Beiträge zur Orientwissenschaft. Edited by Walter Beltz and Jürgen Tubach. Halle: Printing House of the Martin-Luther-University, vol. 34, pp. 113-27.

Böhm, Martina. 2012. Wer gehörte in hellenistisch-römischer Zeit zu "Israel”? Historische Voraussetzungen für eine veränderte Perspektive auf neutestamentliche Texte. In Die Samaritaner und die Bibel. The Samaritans and the Bible. Studia Judaica 70/Studia Samaritana 7. Edited by Jörg Frey, Ursula Schattner-Rieser and Konrad Schmid. Berlin and Boston: De Gruyter, pp. 181-202.

Böhm, Martina. 2017. Jesu Verhältnis zu den Samaritanern. In Jesus Handbuch. Edited by Jens Schröter and Christine Jacobi. Tübingen: Mohr Siebeck, pp. 356-61.

Böhm, Martina. 2018. Samaritanische Diaspora im Imperium Romanum bis ca. 200 n. Chr. In Juden-Heiden-Christen? Religiöse Inklusion und Exklusion in Kleinasien bis Decius. Wissenschaftliche Untersuchungen zum Neuen Testament 400. Edited by Stefan Alkier and Hartmut Leppin. Tübingen: Mohr Siebeck, pp. 171-96.

Bovon, François. 1996. Das Evangelium nach Lukas. Evangelisch-Katholischer Kommentar zum Neuen Testament III/2. Zürich, Düsseldorf and Neukirchen-Vluyn: Benziger-Neukirchener.

\footnotetext{
125 According to the view of Hartwig Thyen John 8,48 is to be understood as a Hendiadyoin which could be paraphrased as: "Aren't we right to say you're one of those crazy Samaritans?" (Thyen 2005, p. 447).

126 (Schnelle 2000, p. 163).
} 
Bruneau, Philippe. 1982. "Les Israélites de Délos" et la juiverie délienne. Bulletin de Correspondence Hellénique 106: 465-504. [CrossRef]

Fiedler, Peter. 2006. Das Matthäusevangelium. Theologischer Kommentar zum Neuen Testament 1. Stuttgart: Kohlhammer.

Frey, Jörg. 2012. “Gute” Samaritaner? Das neutestamentliche Bild der Samaritaner zwischen Juden, Christen und Paganen. In Die Samaritaner und die Bibel. The Samaritans and the Bible. Studia Judaica 70/Studia Samaritana 7. Edited by Jörg Frey, Ursula Schattner-Rieser and Konrad Schmid. Berlin and Boston: De Gruyter, pp. 203-33.

Hensel, Benedikt. 2016. Juda und Samaria. Zum Verhältnis zweier nach-exilischer Jahwismen. Forschungen zum Alten Testament 110. Tübingen: Mohr Siebeck.

Jantsch, Torsten. 2017. Jesus, der Retter. Die Soteriologie des lukanischen Doppelwerks. Wissenschaftliche Untersuchungen zum Neuen Testament 381. Tübingen: Mohr Siebeck.

Kartveit, Magnar. 2009. The Origin of the Samaritans. Supplements to Vetus Testamentum 128. Leiden and Boston: Brill.

Konradt, Matthias. 2007. Israel, Kirche und die Völker im Matthäusevangelium. Wissenschaftliche Untersuchungen zum Neuen Testament 215. Tübingen: Mohr Siebeck.

Konradt, Matthias. 2015. Das Evangelium nach Matthäus. Das Neue Testament Deutsch 1. Göttingen: Vandenhoeck \& Ruprecht.

Kreuzer, Siegfried, Martin Meiser, and Franz Winter. 2011. Basileion I-IV. Die Bücher der Königtümer. In Septuaginta Deutsch. Erläuterungen und Kommentare zum griechischen Alten Testament I. Edited by Martin Karrer and Wolfgang Krauss. Stuttgart: Deutsche Bibelgesellschaft, pp. 714-1037.

Kuhs, Clemens. 1996. Das Dorf Samareia im griechisch-römischen Ägypten. Eine papyrologische Untersuchung. Heidelberg: Institut für Papyrologie.

Lindemann, Andreas. 1993. Samaria und Samaritaner im Neuen Testament. Wort und Dienst 22: 51-76.

Lindemann, Andreas. 2000. Der Erste Korintherbrief. Handbuch zum Neuen Testament 9/1. Tübingen: Mohr Siebeck.

Luz, Ulrich. 2012. Das Evangelium nach Matthäus. Evangelisch-Katholischer Kommentar zum Neuen Testament I/3. Zürich, Düsseldorf and Neukirchen-Vluyn: Benziger-Neukirchener.

Meier, John P. 2000. The Historical Jesus and the Historical Samaritans: What can be Said? Biblica 81: 202-32.

Merklein, Helmut. 2000. Der erste Brief an die Korinther. Kapitel 5,1-11,1. Ökumenischer Taschenbuchkommentar zum Neuen Testament 7/2. Gütersloh and Würzburg: Gütersloher and Echter.

Pummer, Reinhard. 1993. New Testament and the Samaritans. In A Companion to Samaritan Studies. Edited by Alan D. Crown, Reinhard Pummer and Abraham Tal. Tübingen: Mohr Siebeck, pp. 167-71.

Pummer, Reinhard. 2002. Early Christian Authors on Samaritans and Samaritanism. Texts and Studies in Ancient Judaism 92. Tübingen: Mohr Siebeck.

Pummer, Reinhard. 2009. The Samaritans in Flavius Josephus. Texts and Studies in Ancient Judaism 129. Tübingen: Mohr Siebeck.

Pummer, Reinhard. 2016. The Samaritans: A Profile. Grand Rapids: Eerdmans.

Rusam, Dietrich. 2008. Das Lukasevangelium. Die Apostelgeschichte. In Einleitung in das Neue Testament. Edited by Martin Ebner and Stefan Schreiber. Stuttgart: Kohlhammer, pp. 184-207, 229-49.

Schmid, Konrad. 2012. Die Samaritaner und die Judäer. Die biblische Diskussion um ihr Verhältnis in Josua 24. In Die Samaritaner und die Bibel. The Samaritans and the Bible. Studia Judaica 70/Studia Samaritana 7. Edited by Jörg Frey, Ursula Schattner-Rieser and Konrad Schmid. Berlin and Boston: De Gruyter, pp. 31-49.

Schnelle, Udo. 2000. Das Evangelium nach Johannes. Theologischer Handkommentar zum Neuen Testament 4. Leipzig: Evangelische Verlagsanstalt.

Schorch, Stefan. 2012. Der Pentateuch der Samaritaner. In Die Samaritaner und die Bibel. The Samaritans and the Bible. Studia Judaica 70/Studia Samaritana 7. Edited by Jörg Frey, Ursula Schattner-Rieser and Konrad Schmid. Berlin and Boston: De Gruyter, pp. 5-29.

Schröder, Jörn-Michael. 2003. Das eschatologische Israel im Johannesevangelium. Eine Untersuchung der johanneischen Israel-Konzeption in Joh 2-4 und Joh 6. Neutestamentliche Entwürfe zur Theologie 3. Tübingen and Basel: A. Francke.

Sellner, Hans Jörg. 2007. Das Heil Gottes. Studien zur Soteriologie des lukanischen Doppelwerks. Beihefte zur Zeitschrift für die Neutestamentliche Wissenschaft 152. Berlin and New York: Walter de Gruyter.

Thyen, Hartwig. 2005. Das Johannesevangelium. Handbuch zum Neuen Testament 6/1. Tübingen: Mohr Siebeck. 
Weingart, Kristin. 2014. Stämmevolk—Staatsvolk—Gottesvolk? Studien zur Verwendung des Israel-Namens im Alten Testament. Forschungen zum Alten Testament II/68. Tübingen: Mohr Siebeck.

Wengst, Klaus. 2000. Das Johannesevangelium. Theologischer Kommentar zum Neuen Testament 4,1. Stuttgart, Berlin and Köln: Kohlhammer.

Wolter, Michael. 2008. Das Lukasevangelium. Handbuch zum Neuen Testament 5. Tübingen: Mohr Siebeck.

Zangenberg, Jürgen. 1998. Frühes Christentum in Samarien. Topographische und traditionsgeschichtliche Studien zu den Samarientexten im Johannesevangelium. Texte und Arbeiten zum neutestamentlichen Zeitalter 27. Tübingen and Basel: A. Francke. article distributed under the terms and conditions of the Creative Commons Attribution (CC BY) license (http://creativecommons.org/licenses/by/4.0/). 